\title{
Multiple Pathway for Agricultural Labour Adaptation in a Vietnamese Village under the Context of Revonation
}

\author{
Thi Minh Khue Nguyen ${ }^{1}$, Thi Dien Nguyen ${ }^{1} \&$ Philippe Lebailly ${ }^{2}$ \\ ${ }^{1}$ Faculty of Political and Social Sciences, Vietnam National University of Agriculture, Trau Quy. Gia Lam, Hanoi, \\ Vietnam \\ ${ }^{2}$ Faculty of Economic and Rural Development, Gembloux Agro-Bio Tech - ULiège, Passage des Déportés, \\ Gembloux, Belgium \\ Correspondence: Thi Minh Khue Nguyen, Faculty of Political and Social Sciences, Vietnam National University \\ of Agriculture, Trau Quy. Gia Lam, Hanoi, 131000 Vietnam. Tel: 849-4880-8358. E-mail: \\ nguyenthiminhkhue@student.uliege.be
}

Received: May 31, 2019

Accepted: June 24, 2019 Online Published: January 30, 2020

doi:10.5539/jsd.v13n1p97

URL: https://doi.org/10.5539/jsd.v13n1p97

\begin{abstract}
The revival of family farming with rural out migration has undisputable contribution for household livelihoods. This paper aimed to figure out the relationship between migration and agricultural labour adaptation in Vietnamese rural areas. Based on qualitative and quantitative analysis, this study showed that migration had complicated impacts on labour management intra-household for sustaining agricultural activities, there is no remarkable agricultural labour deficit created due to internal migration in the meso level. In contrast with reported trend on de-agrarianization due to productive migrants, this paper argued that rural households manage to have multiple pathways to maintain farming. Their strategy is the combination of changing agricultural scheme, renting labour or develop the multi-spacial household rural households in response with this new context of labour loss for migration. The strong commitments and obligations between family members show that the multi-spacial household model is well-functioning with mutual support divided across space.
\end{abstract}

Keywords: migration, social differentiation, poverty reduction, rural-urban linkage, livelihood

\section{Introduction}

Vietnam still tends to be characterized as a region where farming remains the pre-eminent occupation. Indeed, statistics shows that even Vietnam has recently experienced rapid industrialization and modernization which would lead to the diminishing role of agriculture (Bui Minh 2012, Hoang Xuan Thanh et al. 2013). There has been a change in the structure of GDP whereby the share of agriculture has relative declined from 42 percent in 1989 to 26 percent in 1999 and 21 percent in 2011 while the industry sector has more than doubled from 23 percent in 1990 to 47 percent in 2011 (GSO 2011). Despite the prediction of de-agrarianisation, agriculture is enduring (Hirsch 2011, Peemans 2013). The economy of Vietnam sill depends on agriculture which accounts for more than one-quarter of the GDP, provides $85 \%$ of exports and employs about $60 \%$ of the work force, and a large part of the Vietnamese population (68\%) resides in rural areas which makes farming continue to be the important lives and livelihoods of many Vietnamese, especially the most vulnerable people. In Vietnam, the Red River Delta region in the Northern part shares the common features of agrarian transition undergone by the Doimoi (Innovation Reforms) since 1986. Agricultural land has been converted toward more market and industrial orientation to gain faster economic development (Nguyen Thi Minh Khue, Nguyen Thi Dien, and Ph. 2016, Nguyen Thu Phuong et al. 2008).

Red River Delta region of Vietnam shares the common features of agrarian transition undergone by the Doimoi Reform. Agricultural land has been converted toward more market and industrial orientation to gain faster economic development. According to the recent National Survey on Land, in a decade from 2000 to 2010, the non-agricultural land increased 89000 hectares while the land for rice production decreased more than 34000 hectares annually (Nguyễn Ngọc Công, 2012). The overall number of landless farmer households in the region was 3.3 percent in 1999, 13.9 percent in 2002 rose up to 22 percent 2012 (FAO, 2014). Red River Delta historically is also the densest populated region in Vietnam with average 0.04 hectares per head. Therefore, since late 1990s this region witnessed a significant increase of off-farm business ever. Rural households often adopt 
more than one strategy to diversify their livelihood such as intensifying agricultural production and diversifying their economic activities in non-farm business. It is noteworthy that this area have a good infrastructure and transport link allows people to seek employment in the capital Hanoi and other local urban centers without the need of leaving their hometown permanent. Rural out migration on one hand is manifest to have been an integral component of the sustainable urbanization and national economic transition. On the other hand, migrating labours have become an important source of labour in urban areas and industrial zones during this process (Anh 2003, 2008, White, Djamba, and Anh 2001). Various research studies in Vietnam conclude that migration is among key household and individual strategies in response to both economic difficulties and livelihood opportunities. However, the impacts out-migration have had a complex and multiple dimensions on agriculture and the rural areas. Given that those who migrate out are likely to be productive labour for farming, this paper tries to unveil the different pathways of rural household allocated their labour resource in order to sustain agricultural production.

\section{Methodology}

The fieldwork was conducted in 2015 in Maithon Village in Chi Lăng Commune, Que Vo District, Bacninh Province in Vietnam. "Làng" (village) was one of the most typical institutions of ancient Vietnamese society (Dũng, 2010; Gourou, 1945). Paul Mus (1952: 240) stated that "Vietnam is a network of villages" and he emphasized "it was villages that produced Vietnam and it was in them that one learned to apprehend it, at decisive times, in its national spirit" (Mus, 1952:21). Every village had its own lands, agricultural practices, its own property and its own justice, with distinct traditions, cultures, politics and economics (Khoang, 1966) Therefore, a village has been viewed as the most appropriate entry point for research into rural conditions and change in rural Asian and particularly in Vietnam studies. In this thesis, I choose Maithon as one typical Vietnamese village of Bac Ninh province in Red River Delta of Vietnam to do research. Bac Ninh is located in Red River Delta, about $30 \mathrm{~km}$ far north from the capital Ha Noi, along the recently upgraded National Highway 1A. Sharing the same characteristic with other villages in Red River Delta, Maithon was chosen because firstly this village has experienced dramatically change due to modernization process of Doimoi, in which the high level of migration is one of fundamental characteristics (Rigg \& Vandergeest 2012). Secondly, Maithon socio-economic conditions are characterized by monoculture in rice production and before its first high wave of temporary migration in 2005 , the village population was mainly leaned on farming as the only source of income. Until now, it is considered as the lowest on economy status due to having no industrial zone, no traditional handicraft as other villages, and very limited dynamic non-farm business diversification and at far distance from capital of province $(30 \mathrm{~km})$. Thanks to its mono-source of earnings in rice production, the Maithon household income in 2005 could be recalled based on their agricultural land areas which had statistics record. Besides, monoculture gives me a chance to isolate the impact of circular migration with the rural areas from other factors.

In this paper, I use both qualitative and quantitative data. The qualitative data come from two sources. The first source is published and unpublished data of the agricultural land, the village, and the commune. The second source is observations, interviews and conversations during fieldwork. The quantitative data come from the survey which were carried out in 2015. In addition, I also use population statistics and socio-economic data provided by the commune, particularly those related to land use and labour. Overall, Mai Thon village has 158 households (up to July/2015) which include 699 villagers. I did interview with 128 households, equivalent with $81 \%$ of the whole village household number. There are still 30 households that I could not make interviews. These cases are households who are long-term migrating or they are only too small children who cannot be interviewed. However, I still collect the general information of these household from Hokhau book (which is updated to 9/2014). The systematic survey divided 128 households in the village into four groups, detailed as below:

Group 1: includes the households whose family member(s) participated out of village and short-distance migration which permit them commuting daily during the last 12 months. There were 42 households in this group.

Group 2: Migration households: family member(s) only migrate for work out of province, and normally is long-distance during the last 12 months. This type of migration is much diversified, including both national and international migration, seasonal and long-term migration. There were 23 households in this groups. In fact, 30 inacessible households were belonged to this groups however I could not conduct the information from them.

Group 3: Mixed migration households: family members participated in both types of short-distance and long-distance migration during the last 12 months. There were 42 households in this group

Group 4: Non-migration households: none of family member participated in any types of migration during the 
last 12 months. At the time 2015, there were 21 households which all of their members stayed in the village, and conducted no migrating activities. However, among these 21 households, there were 6 households which fell into the sick and/or the alone elder cases, in other words, they were considered as incapable of working, living under the poverty line and totally leaning on the social allowance. Thus, I abstracted these number of households out of this categories and the total households in this group was only 15 left.

The systematic questionnaire investigation and participatory observation were to provide a broader picture, while the in-depth interviews and biographies were specifically directed to provoke a profound illustration of the peasant's daily life, their perceptions related to farming labour management.

\section{Findings and Discussions}

\subsection{Main Features of Correspondent Households}

Even though the industrialization process started in Bac Ninh province since 2001 with the enormous agricultural land acquisition to build up the industrial zones, Mai Thon village totally stood out of this movement. However, associated with the rise of industrialized zones nearby, the village's agricultural labors have opened the chances to find an extra non-farm jobs. This dramatically effected on the changes in labor structure of farm households. Table 3.1 described the main characteristics of surveyed households in which demographic features of households are focused, includes household/family size; labour size, migration labour size. Household size indicates how big a family is - it is a unit of measurement used to show the number of members living in a family, consisting of parents, children and others. Household size depends on couples' birth rate and model of different generations living together in a family. In traditional Vietnam agricultural society, a big number of offspring is a symbol of a prosperous family, and satisfied a big amount of manual labor was needed, which resulted in a high birth rate and big household size. Also, many Vietnamese generations lived under the same roof. Whereas in the process of industrialization in recent years Vietnam, the birth rate is low and grown up children do not live with their parents, so the household size is smaller (Bergstedt 2012). The household size of Vietnam decreased from 5.22 persons per household in 1979 to 4.48 persons per household in 1989, 4.61 persons per household in 1999 and this number was 3.8 in 2009, declining by 0.81 person compared with 1999 .

Table 1 shows that the average family size of Maithon household is 4.6 people which is higher than the average family size of Red River Delta (3.79); rural areas region (3.9) and the national (3.8) according to the 2009 Vietnam population and housing census conducted on April 1st 2009. It goes with the claim that Bacninh is the highest density population city in Red River Delta and in Vietnam. This mainly due to the families in Maithon keep living three or more generations under the same roof rather than the high birth rate. Among four groups, the smallest households size is the non-migrant (4.3) while the largest one is the family who pursuit migration for long distance (5.1). While the labour size of the three migration household groups are relatively equal $(2.7 ; 2.8$ and 2.8), the migration size of the research groups are quite different, in which the migration labour of the group 3 is highest 2.3 person per household. 
Table 1. The socio-economic charateristics of survey households

\begin{tabular}{|c|c|c|c|c|c|}
\hline Indicators & $\begin{array}{l}\text { Group } 1 \\
(\mathrm{n}=42)\end{array}$ & $\begin{array}{l}\text { Group } 2 \\
(\mathrm{n}=23)\end{array}$ & $\begin{array}{l}\text { Group } 3 \\
(\mathrm{n}=42)\end{array}$ & $\begin{array}{l}\text { Group } 4 \\
(\mathrm{n}=15)\end{array}$ & $\begin{array}{l}\text { Total } \\
(\mathrm{n}=122)\end{array}$ \\
\hline \multicolumn{6}{|l|}{ Household labour } \\
\hline Family size (mean, pers.) & 4.8 & 5.1 & 4.6 & 4.3 & 4.6 \\
\hline Labour size $^{1}$ (mean, pers.) & 2.7 & 2.8 & 2.8 & 2.6 & 2.5 \\
\hline Male labour (mean, pers.) & 1.4 & 1.5 & 1.4 & 1.2 & 1.3 \\
\hline Female labour (mean, pers.) & 1.3 & 1.3 & 1.4 & 1.4 & 1.2 \\
\hline \multicolumn{6}{|l|}{ Migration labour } \\
\hline Mean, pers. & 1.8 & 1.9 & 2.3 & 0 & 1.5 \\
\hline Number of migrants (pers.) & 76 & 43 & 98 & 0 & 219 \\
\hline Male migration labor ${ }^{2}$ (mean, pers.) & 0.9 & 1.0 & 1.1 & 0 & 0.8 \\
\hline Female migration labour (mean, pers.) & 0.8 & 0.9 & 1.2 & 0 & 0.7 \\
\hline \multicolumn{6}{|l|}{ Agricultural land } \\
\hline Agricultural land (1993, mean, $\left.m^{2}\right)$ & 1706.4 & 1931.3 & 1632.5 & 2169.0 & 1859.1 \\
\hline Agricultural land (2014, mean, $\left.m^{2}\right)$ & 1724.6 & 1763.8 & 1543.6 & 2350.0 & 1808.8 \\
\hline
\end{tabular}

Source: Household survey 2015

In term of land holdings, there were only very small exchanges among villagers and land conversion for commune purposes since the agricultural land market is not well developed in Vietnam in general and in Bac Ninh in particular. Overall, the farm households cannot sustain their livelihoods with small land areas therefore they had to find an off-farm job and outside the village. However, the overall trend was observed that most of the group maintain their own agricultural land, except for the slight decrease of group 2 and increase of group 4 in landholdings in comparison between the year 1993 - the moment of land redistribution in Vietnam and in 2015. Without migrating members, this group of non-migration households were likely to rent more land of the migration households in the village or commune to expand agricultural production. However, it should be notice that they rarely expand their agricultural production into large scale farm. Wet rice production in Vietnam requires considerable labour input, especially during transplanting and harvesting. Therefore, literature reported that the movement of people from farm to non-farm employment and from rural to urban areas typically causes agricultural labour shortages, and forces farmers to adapt their farming techniques. In the Southern of Vietnam (Mekong River Delta), farmers have mechanized rice production (Hoang Xuan Thanh et al. 2013). However, in the Red River Delta, the household division of labour and production process will easily adapt to the out-migration of one or two members, and to the subsequent relative labour shortage and decreased flexibility in production sphere.

\subsection{Labour Management in Agricultural Activities}

In Maithon, the consequence of the loss of a household member was found generally unproblematic to agricultural production, here mostly is rice production. A large majority of respondents ( 91.5 percent) indicated that their households did not suffer a negative impact due to the loss of labour. This can be explained in part by the large population which resulted in a huge labour surplus and limited land. Only few households expressed that because of migration to international, or moving around the Southern part of Vietnam, the migrants cannot easily come back during the peak period of the harvest, some labour shortage occurred, but its effects have not been drastic. Table 2 shows $74.8 \%$ Maithon households rearrange their internal labour for rice cultivation. As already discussed in the previous section, rice production is considered as the fundamental agricultural activities in this village because on one hand, it does not take as much time and labour care as other agricultural activities; on the other hand, unlike other agricultural activities, rice production has high demand labour at only some periods of season; therefore households could concentrate their labour members elsewhere. Table 2 shows rice production witnessed more potent exchanging and renting external labour than other farming activities. Among

\footnotetext{
${ }^{1}$ Included migration labour

${ }^{2}$ Migration labour at the research time 2014-2015
} 
the migration households, group 3 witnessed the highest proportion of households participated in labour exchange (50\%); while the group 2 showed the lowest percentage (21.4\%). The main reason was reported that majority of group 3 migrated in the North of Vietnam, therefore they can manage to come back and help in the peak time. However, their free time is quiet limited, thus they need more supported from their network. In order to organize this labour input, Vietnamese farmers mutually depend on each other for a certain level or cooperation (Bergstedt 2012: 151). Mutual help still plays an important role for the farmer to adapt with labour shortage in the season time. Mutual help or non-commercial labor exchange is expressed in Vietnamese as "đổi công", which was a common form of mutual aid from old times in Vietnamese traditional villages as well as in many other Southeast Asian countries. This normally occurred on a small scale among 5-7 relatives or neighbor families, to meet the needs of seasonal agricultural tasks that had to be completed in a few days, such as preparation of rice fields, seedling transplantation, irrigation and harvesting (Minh, Nga, and Phương 2012, Mus 1952)

Beyond its economic functions, this exchange labour strategy seems to create a social connection which offers family groups a portion of the means necessary for them to evolve and reproduce and, by extension, the development and reproduction of the local society as a whole. At the same time, it maintains family units in a local network of interdependence and in certain situations, it can be used as a tool of exclusion. Although this kind of mutual help is often thought to be deteriorated with migration, mechanization, and monetization of agricultural production, our survey results show $34.3 \%$ reported that members of their households exchanged labour (either help other households and/or received help from their neighbours and their relative households) in the year prior to the survey. It is interesting that wage labour and mutual help both play an important role. Even though mutual help is decreasing over the years while paid labour is increasing, only 18.2 percent of households claimed they rented external labour. The following case studies illustrate how rural households cope with the change resulting from out-migration.

Table 2. Labour management in agricultural production activities

\begin{tabular}{|c|c|c|c|c|c|c|c|c|c|c|c|}
\hline \multirow{2}{*}{ (Unit: hhs) } & & \multicolumn{2}{|c|}{ Group $1(\mathrm{n}=42)$} & \multicolumn{2}{|c|}{ Group 2(n=23) } & \multicolumn{2}{|c|}{ Group $3(n=42)$} & \multicolumn{2}{|c|}{ Group $4(n=15)$} & \multicolumn{2}{|c|}{ Total $(\mathrm{N}=122)$} \\
\hline & & $\mathrm{N}$ & $\%$ & $\mathrm{~N}$ & $\%$ & $\mathrm{~N}$ & $\%$ & $\mathrm{~N}$ & $\%$ & $\mathrm{~N}$ & $\%$ \\
\hline \multirow{4}{*}{ Rice production } & No practice & 3 & 7.1 & 9 & 39.1 & 8 & 19 & 3 & 20 & 23 & 18.9 \\
\hline & Family labour & 32 & 82.1 & 7 & 50.0 & 23 & 67.6 & 12 & 100 & 74 & 74.8 \\
\hline & Exchange labour & 12 & 30.8 & 3 & 21.4 & 17 & 50.0 & 2 & 16.7 & 34 & 34.3 \\
\hline & Rent labour & 6 & 15.4 & 7 & 50.0 & 4 & 11.8 & 1 & 8.3 & 18 & 18.2 \\
\hline \multirow{4}{*}{ Cash crop production } & No practice & 39 & 92.9 & 23 & 100 & 42 & 100 & 14 & 93.3 & 118 & 96.7 \\
\hline & Family labour & 3 & 100 & 0 & 0 & 0 & 0 & 1 & 100 & 4 & 100 \\
\hline & Exchange labour & 0 & 0 & 0 & 0 & 0 & 0 & 0 & 0 & 0 & 0 \\
\hline & Rent labour & 1 & 33.3 & 0 & 0 & 0 & 0 & 0 & 0 & 1 & 0.8 \\
\hline \multirow{4}{*}{ Pig production } & No practice & 41 & 97.6 & 22 & 95.7 & 41 & 97.6 & 9 & 60 & 113 & 92.6 \\
\hline & Family labour & 1 & 100 & 1 & 100 & 1 & 100 & 6 & 100 & 9 & 100 \\
\hline & Exchange labour & 0 & 0 & 0 & 0 & 0 & 0 & 0 & 0 & 0 & 0 \\
\hline & Rent labour & 0 & 0 & 0 & 0 & 0 & 0 & 0 & 0 & 0 & 0 \\
\hline \multirow{4}{*}{ Poultry production } & No practice & 32 & 76.2 & 20 & 87 & 34 & 81 & 4 & 26.7 & 90 & 73.8 \\
\hline & Family labour & 10 & 100 & 3 & 100 & 8 & 100 & 11 & 100 & 32 & 100 \\
\hline & Exchange labour & 0 & 0 & 0 & 0 & 0 & 0 & 0 & 0 & 0 & 0 \\
\hline & Rent labour & 0 & 0 & 0 & 0 & 0 & 0 & 0 & 0 & 0 & 0 \\
\hline \multirow{4}{*}{ Castle production } & No practice & 39 & 92.9 & 22 & 95.7 & 41 & 97.6 & 13 & 86.7 & 115 & 94.3 \\
\hline & Family labour & 3 & 100 & 1 & 100 & 1 & 100 & 2 & 100 & 7 & 100 \\
\hline & Exchange labour & 0 & 0 & 0 & 0 & 0 & 0 & 0 & 0 & 0 & 0 \\
\hline & Rent labour & 0 & 0 & 0 & 0 & 0 & 0 & 0 & 0 & 0 & 0 \\
\hline
\end{tabular}




\begin{tabular}{lllllllllllll}
\hline & No practice & 40 & 95.2 & 22 & 95.7 & 42 & 100 & 12 & 80 & 116 & 95.1 \\
Aqua-culture & Family labour & 2 & 100 & 1 & 100 & 0 & 0 & 3 & 100 & 6 & 100 \\
& Exchange labour & 0 & 0 & 0 & 0 & 0 & 0 & 0 & 0 & 0 & 0 \\
& Rent labour & 0 & 0 & 0 & 0 & 0 & 0 & 0 & 0 & 0 & 0 \\
\hline
\end{tabular}

Source: Household survey 2015

Ms Hang was born in 1962. She was a farmer and junk trafficker in Hanoi. Her husband, Mr Chi was born in 1959 was a farmer and a bricklayer. She has three children and his household has seven sào of agricultural land allocated by the commune. Before 2005, she had rented five extra sao from her cousin to grow rice. Since 2005, her children had grown up and settle down in other localities, she followed the villager migrated to Hanoi to do junk trafficked and house helper; therefore she gradually return the rented land. Recently, her household only keep farming on their own agricultural land. She also rented 2 sao for her neighbor so, she only farms seven sao in total. Because, their household now only have two working labourer - her and her husband who both have migrated out for work. Thus, during the planting and harvesting seasons she is obliged to exchange labour with other households in the commune. She now lives in Hanoi, but she will come back in the season time to transplant rice seedling or to harvest. Because she only has few days off therefore she needs help from some relatives and neighbours. She herself even worked on the field whole night to pull-up rice seedling and prepared for the helpers to work on the next days. Before, she would transplant back for these helper households with the same amount of working days as the labour exchange. But now she is busy, she would help for fewer transplanting day. The rest, Mr Chi would plough for exchange because her household have a plough or her husband also sometimes helps these households repair their houses, using his bricklaying skills. The example of Ms Hang's household shows that the exchange of labour does not necessarily diminish in a context of agricultural change, monetization, and labour out-migration. In a context of out-migration and the rental of additional land, the practice of exchanging labour remains relevant for many households who lack the labour to work their land. Labour exchanges between households are flexible and can be deployed for a range of agricultural and, sometimes, non-agricultural activities. Besides exchanging equal days for equal types of work (transplanting or harvesting, for instance), labour exchange may, as the example of Ms Hang household illustrates, also involve exchanging one kind of work or service (ploughing, bricklaying) for a day of harvesting. This exchange of farm labour perceived through the lens of the government's economic and developmental aspirations would be considered as "backward"" and inefficient (Hoang Ba Thinh, 1998:11-12, Taylor 2007). It did not contribute to a more industrialized, professionalized, and efficient agricultural sector. However, from the perspective of family and household maintenance, these labour exchange provided a network of support and mutual assistance. At the same time, these labour arrangements enhanced the preservation of a sense of village sentiments. It also facilitated villager's opportunities to involve in money-generating activities outside the household. Besides, it preservers the solidarity between kin and neighbours, somewhat reduced the contradictions between the commercial and the communal values of farm work (Shreeves 2002:227-228). Labour exchange in rice cultivation often involves relatives or neighbouring households working on each other's land. Ms Hang noted: "For the winter-spring crop when I have more free time, I would help my related households for five days in transplanting rice. The households that often exchange labour with my household are Ms Van's household and Ms Lim's household - who are my sisters; and the households of Ms Lan, Mr Manh, Ms Nhuan - who are in my husban's patrilineage." Monetary contributions were, of course, important for the households, but it was not sufficient to hold a community together. And to some extent, transactions of money served to undermine the feeling of solidarity as the short-term and unequal aspects of these arrangements set the villagers apart for each other (c.f. Douglas 2003:147-148).

While this shows the continuity of labour exchange, the modalities for labour exchange have changed. As Bergstedt (2012: 162) has also observed in the north of Vietnam, the increased access to money "provided the option of hiring labour, and organizing work in a way that released people from the time-consuming task of recompensing other people's labour efforts by an equivalent amount of working hours." Table 12 showed that 18.2\% of Maithon household who still keep rice cultivation did rented external labour. Among that, fifty percent of group 2 households need this labour source to maintain rice production. However, due to rented labour on one hand is restricted to certain kinds of activities, on the other hand it increased the production cost so high that in many case, Maithon households combined it with renting and lending out their own land. As case of Ms Hang, she now lends out 2 sao of their land for Ms Van, her sister for free. When we asked Ms Hang why, instead of renting out her land she did not hire labourers, she noted that hiring labour is costly and that a lot of other work still remains to be done 
- for which she has no time and strength. She therefore only cultivates five sao of land needed to grow sufficient rice for the household's own consumption. The experience of Ms Hang illustrates the relationship of mutual dependency that exists between those with a land surplus but labour deficit, and vice versa. In assessing the nature of such relationships - and whether they are exploitative, for example - it is necessary to consider the place of rice farming within the context of wider household livelihoods. Rice cultivation is carried out on a very small scale in the village, and rarely generates any profit, as such. Growing rice is largely for household consumption rather than for sale. This means that viewing the renting of land and the hiring/exchanging of labour in the village through the lens of 'exploitation' misrepresents the nature of such transactions. These are, in effect, production management arrangements, often undertaken between relatives, to maximize production and smooth out scarcities at the household level. The notion of 'exploitation' in such a context does not grasp the nature of the agreement and the relationships that underpin them. Whether this extends to other villages in Northern Vietnam it is hard to say. Another important factor influencing the exchange of labour is the mechanization of agricultural production. Rice cultivation has become less labour intensive due to the mechanization of ploughing and transportation. These are activities that are increasingly paid, instead of exchanged for labour. This mechanization of agricultural labour has, to some extent, also facilitated a feminization of rice cultivation. With many husbands and adult sons absent working elsewhere, women are now often in charge of growing rice for the family consumption. Ms Linh, for example, works on her own four sào of land as her husband is migrated to the South and her daughters are too young to be of much help. She noted: "Farming is always the heavy work. But it has been mechanized a lot so it is ok for me. Before I rented machines for ploughing and for the harvest, but few years ago, I also rented harvested machine right to the paddy field bank. I just need to transport the rice packages by motorcycle home. All is door to door service if you have money. Of course, it is costly, so as far as my husband sent money back home, I could manage to do farming on my own because it is less manual than before."

\subsection{Multiple-Site Household: Labour Adaptation under the Context of Migration}

In three ways of labour management for rice production, table 1 highlight the internal household adaptation. 74.8 percent of households reported that they keep their rice production at the level that their own family member can rearrange. Among migration groups, group 1 has 81.2 percent of households prefer this approach. Figure 1, 2 and 3 shows the differences between the labour divisions of three migrating households groups. It is noteworthy that in Vietnam migration is the household decision making which need the suitable arrangement among their members' possibility and profit (Hoang Lan Anh and Yeoh 2011). Household membership is usually defined as living "under the same roof", however, under the context of Vietnam industrialization recently, this concept is gradually changing into a diversified models. Figure 13 describes the case study of Ms Ha who is typical for household in group 1. Ms Ha is 35 years old, she is a worker in Canon company which located in Que Vo IP and around 25km from home. Her company has bus to pick up their worker so she chose to go back and forth daily for work. Her husband, Mr Cong is a small building contractor and he normal takes the projects in Bacninh province and nearby surroundings which permit him to go home every day. Unlike other freelance bricklayers in Maithon who only works around 15 days per month, Ms Ha's husband is quiet busy and normal works for 25 days per months. Ms Ha household has 4.5 sao paddy field which had divided for Mr Cong and his parent in 1993. Because Mr Cong's mother lived with him, this paddy field belong to his family. Her family lent 2 sào for free from Mr Cong's brother, so they cultivated 6.5 sao in total. His mother is 65 years old and she is in good health condition therefore she would be responsible most of farming daily care works. Ms Ha and Mr Cong will help in their break days. In peak season, Ms Ha would even change her working shifts from day into the evening to do farming while her husband would take few days off. This is interesting because even though Mr Cong income is reported much higher than $\mathrm{Mr}$ Ha salary, he keeps helping his wife and her mother by himself instead of renting labour. He considered it is his way of sharing which hiring labour cannot show. This labour arrangement illustrated the flexibility in rural household labour division. Two main labour in Ms Ha family keeps migrating daily for work and practicing agriculture at the same time. These arrangement maximize their earning opportunities while reduce the risk of migration. It cannot stand to mention about the involvement of the uncategorized labour - their mother. She not only contributes in farming work, as well as non-farm activities, but also has importance role in reproductive work of their family. In turn, the young family member also do the support in both farm and non-farm work. 


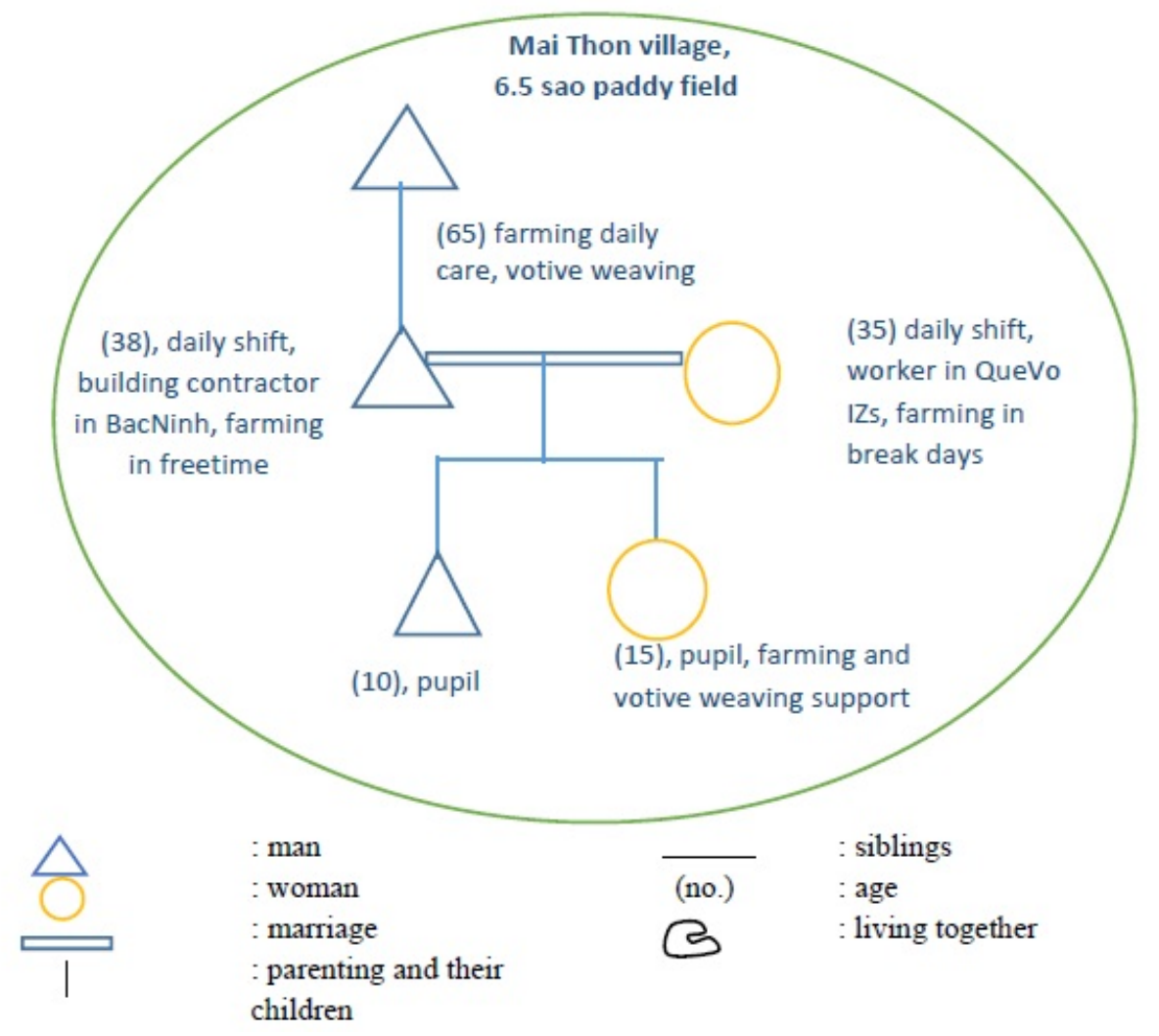

Figure 1. A model of labor division of Group 1 household

Figure 2 describes the typical model of group 2 household labour arrangement. The person is interviewed is $\mathrm{Mr}$ Ta, 24 years old, the oldest son in the family of Mr Nguyen Van Tin and Ms Pham Thi Trung. Mr Tin and Ms Trung got marriage in 1990, and in 2000 migrated to District 12 in HoChiMinh city to participate in garment manufacturing outsourcing sector. Among many Maithon households who migrated to the South in 2000, his family is one of the few who could settle down in Ho Chi Minh City until now. His family was divided 4.5 sao paddy field. Even though his family only come back home in Tet - Lunar New year and some important kinship social events, they keeps their land use right. Before these paddy field was mainly taken care by his grandparents. However, they become old and weaken, therefore his family decided to let him return to the hometown. On one hand, he can look after his grannies and their paddy field; on the other hand, he could settle up his own family here. Although living in HoChiMinh for a long time, he felt comfortable with the rural lifestyle therefore he keeps all his acquaintances. His wife is his childhood friend and she is a hair dresser. He is now the taxi driver and helps her grandmother farming. However, because his wife is pregnancy and he is also busy, he need to hire a lot for rice production from ploughing, transplanting and harvesting. Therefore his faming activities mainly aim to keep their own land used right. His parent intended to return Maithon as well, due to the main reason that they do not want their children have marriage in the South and will leave the ancestral land. His parent intend to open the sweatshop in Bacninh, combine with Thuy village for business rather than come back to agriculture. Because on one hand garment manufacturing is his family's strength, and on the other hand, their land is two small which had already pushed them to migrate in 2000s. 


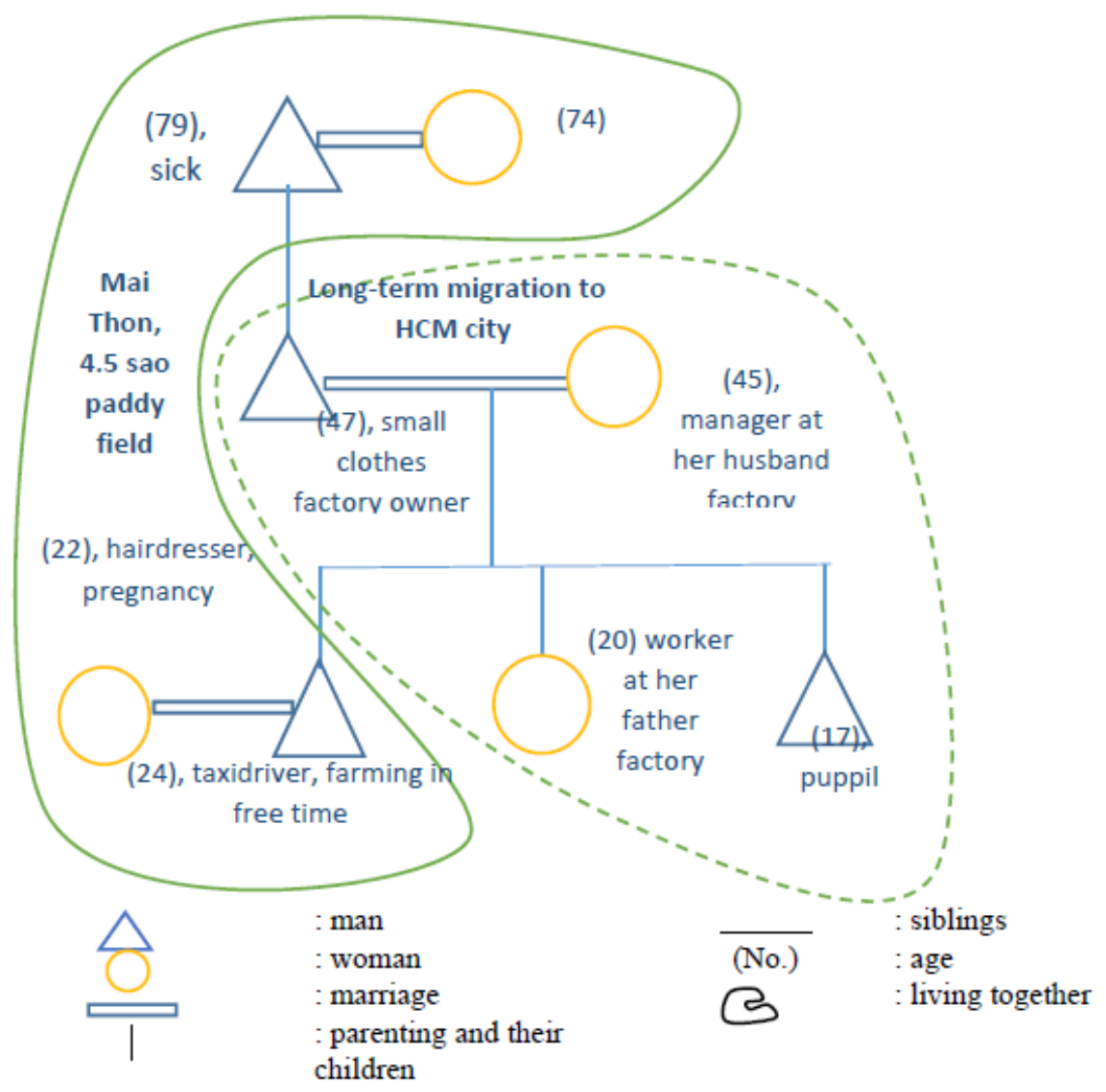

Figure 2. A model of labor division of Group 2 household

Mr Ta case demonstrated for many aspects in the relationship between migration and agricultural production. Firstly, this case study remind us about the closed and flexible linkage between migrants and their family. It is important that the labour arrangement among family members changed over time. It much depend on the members' abilities and wish. When Mr Ta grandparents were strong and had ability to be responsible agriculture and family work, the whole family of Mr Ta could migrate. Recently when the grandparent are weaken, $\mathrm{Mr} \mathrm{Ta}$ was sent home to take the responsibilities in both production and reproduction work which supposed belong to his father according to traditional norm. Second, it could be observed that the older generation mostly take care of the paddy field by themselves and exchange labour, the youth are likely to rent labour to farm and they could complete their multiple works. In other words, they does not much concern about the profit from farming, but practicing rice cultivation mostly aim to land keeping. It's cohesive with the finding about the relationship between migration and agricultural land in the part 6.1. Fourthly, it is noteworthy that long-term migration does not need to end up in permanent movement, especially in the context of Vietnam, where the feeling of homeland - ancestor's land stay in the blood of the villagers. Therefore Mr Ta could return home for marriage, and their parents intend to start up again in their hometown. In other words, there is the complex and multi-layer in migration process of rural household. It is not only a household could involve different types of migration at the same time, but also each household member could experience and move from this migration type to another suitable types following their household's strategy. This leads to unpredictable result in the impacts of migration on agricultural production in Vietnamese village. In case of Maithon, it seems provoke the positive side however, it hard to generated this outcome. 


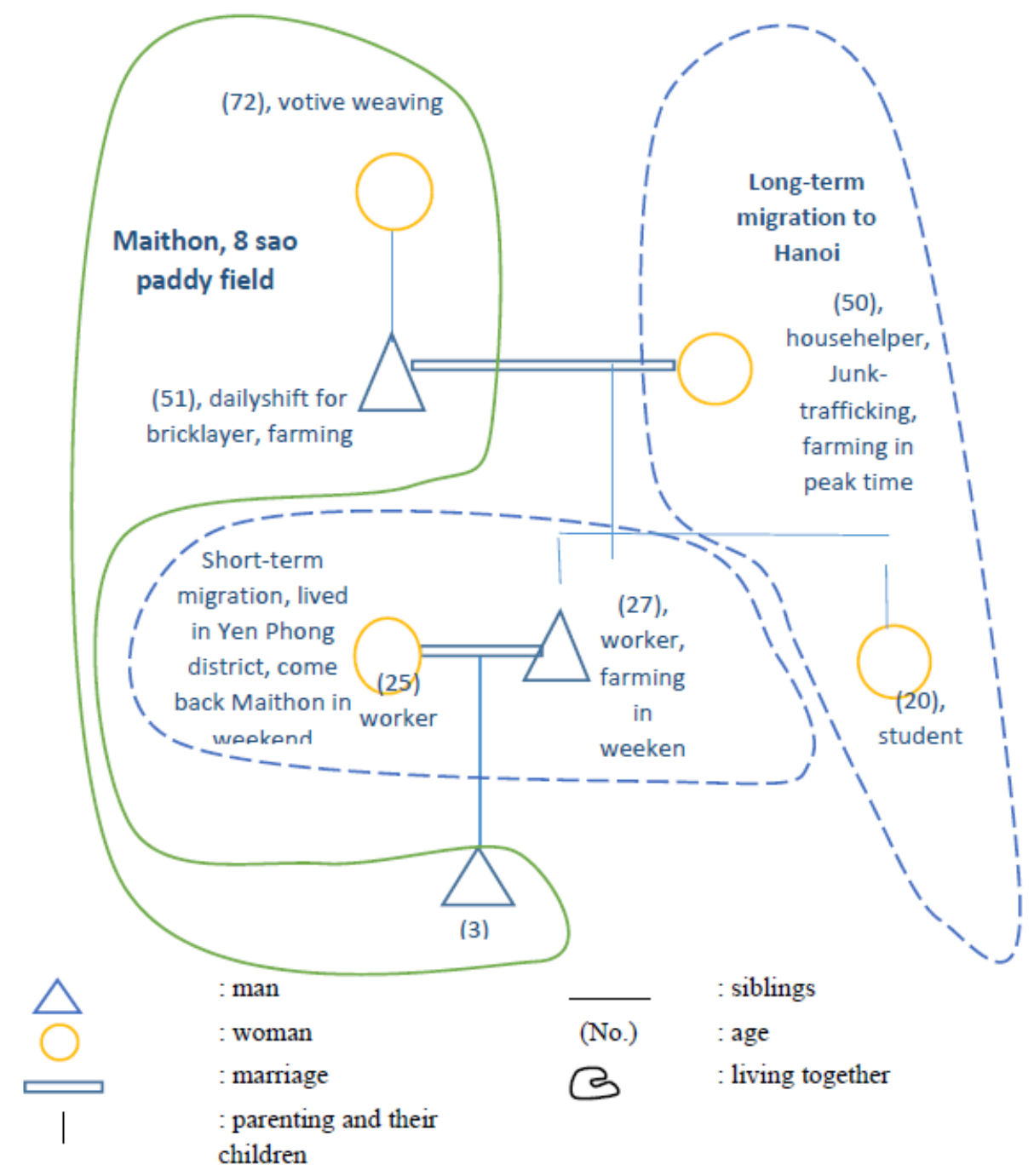

Figure 3. A model of labour division of Group 3 household

According to the 2009-2010 peasant survey, in northern rural areas there exist very few peasants who work full time as farmworkers, even among landless households: a little more than $10 \%$ of interviewed households in the Red River Delta have members working as farm wage laborers (Bùi Quang Dũng 2011: 17). A report of the International Food Policy Research Institute (IFPRI) in 1996 found that while hired labor represented 33-39\% of the total labor use in the Mekong Delta, the figure was just $5 \%$ in the Red River Delta (as cited in Minot \& Goletti 2000: 14).

Figure 3 demonstrated for the typical labour division in group 3. Mr Lam, 55 years old is a farmer and a bricklayer. His household divided 8 sao of land in 1993, however, they renting out 2 sao for their relatives since 2013 so they only cultivated in 6 sao in total. He usually go for construction building for around 15 days per month around Bacninh province which permit him to go home daily. He is now living with his mother who is 72 years old and still votive weaving and take care of her grand grand-children. Mr Lam's wife has taken the long-term migration to Hanoi since 2011, following her cousins to do junk-trafficking and freelance household cleaner. One of the importance reason which pushed her migrate is because their daughter graduated high school and applied to be the student in the Commercial University. She moved to Hanoi for working and living with their daughter. Most of the farming daily care such as nitrogen/ potash/ phosphorus fertilizer, insect pest control, weeding... would be taken by Mr Lam and his son when he has free time in weekend. Mr Lam's wife will take off one week per season come back home for rice transplanting and some days for harvesting.

Regarding to harvesting, peasants in the Red River Delta recently can choose doing manual or/and renting combine harvester. Renting a machine for harvesting is even cheaper and faster than renting laborers for manual 
harvesting. Harvesting machines cost around 150,000 VND per day while renting a laborer for manual harvesting ranges from 250,000 VND to 300,000 per day and the harvesting machine can finish one ha in a day while manual harvesting need three days. However, harvesting machine only can used in dry and large area paddy field; combine with the given condition that rice needs to be ripen evenly. Besides, if a storm or monsoon happened in the harvesting time, the machine could not be used as well. Moreover, Bac Ninh peasants usually choose manual harvesting in the winter-spring season, because following this season they will grow some cash-crops. If the paddy is harvested by machine, it would create deep field trenches which make water drainage vegetable grow difficult. Therefore, they normally rent harvesting machine in the summer-autumn rice season. Mr Lam's wife reported that if she did not return home for transplanting and harvesting, their household hardly continue rice cultivation. The oldest son is 27 years old and has been working in Yen Phong IZs since he finished high schools. He met his wife in his work place and got married in 2000. They are now both working for Samsung Electrics Company and took a rented room near their factory. Because their son is living in Maithon with Mr Lam and the grand grandmother, they come back home every weekend. He also gives supports in farming when his father is absent for work. The case of Mr Lam's household consists three types of migration, including daily-shift, short-term migration and long-term migration combined with the non-farm activities. This case is strong evidence to illustrate that multiple jobs holdings does not need to erase agricultural production as long as it has suitable labour arrangement. From other perspective, migration could show an excessive combination with farming as long as it keeps circular. However, it does not much effected on the rice cultivation in Mr Lam's household because his household continuously farming. They manage by the well arrangement among family members.

In sum, three model of three migration household groups shows the expansion of multifunction households and multi-spacial households. Maithon shows the same picture with other rural household in Red River Delta that majority of them cannot be referred to as "farming households" but instead as "rural households which continue to farm" as (Nguyen Thi Dien et al. 2015, Nguyen Thi Dien, Lebailly, and Vu 2014). These case studies challenge the traditional concept of household when defined them as "members living under the same roof". The strong commitments and obligations between family members show that this household model is well-functioning with mutual support divided across space. It illustrated for the multi-spacial household which is recently popular in Vietnam. In rural areas, people who are already married tends to migrate more than people who is unmarried. The reason for this can be attributed towards cultural differences between Vietnam and other countries. In the west, the most important precondition for a "family" is for the unity of the family at a specific residence (Qian, 1996); therefore individual migrating decisions of the man in a family can severely affect the harmony. However, in Vietnam, like other eastern countries, living together is less important than loyalty to each other. Multifunctional farms that emerge from processes of repeasantization, as Van der Ploeg suggests are in essence, a modern expression of the fight for autonomy and survival in a context of deprivation and dependency".

Even though there is not significant labor deficit happened due to migration, figure4 shows that it does effect on amount of works on people who stay. 100 percent of households in group 3 claimed that they need to carry more agricultural work even though they could involve different types of support from labour exchange, hiring labour, reduce farming activities and renting out part of their agricultural land. The main reason is because they release the highest migrating labour. While the group 1 and group 2 has the similar proportion of households claim on the heavier work, the reasons are reported very different. While group 1 mostly based on the suitable family labour arrangement and labour exchange, group 2 mostly use rented labour to to reduce the burden of farming works. 


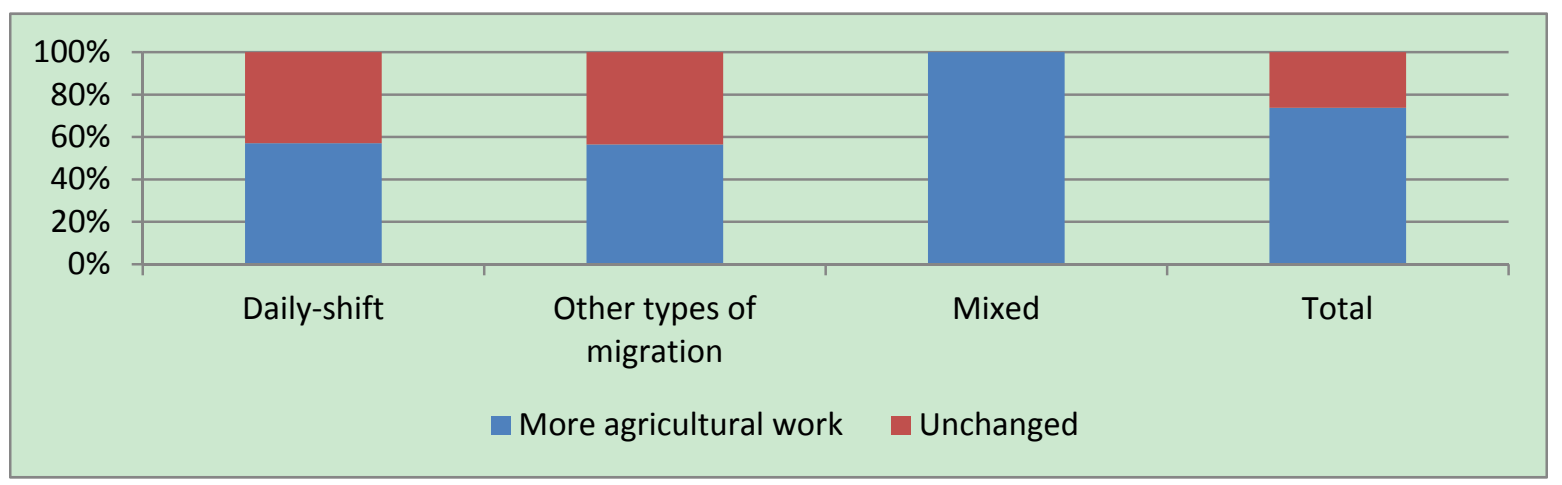

Figure 4. Agricultural work division after migration

Source: Household survey 2015

Vietnamese agriculture has traditionally relied predominantly on human and animal labour and little on engine-power machines. Mechanization has increased quite significantly over the past decade however, driven by such factors as riing labour costs, incresed attention to reducing post-harvest losses, and the development of specialised forms of agricultrual production in livestock and horticulture. Some type of machinery was used on more than 90 percenet of paddy farms for land preparation and threshing. Machine for other funtions was more variable -23 percent for seeding, 78 percent for harvesting and 14 percent for drying. Tractors, water pumps, and various forms of mechanical harvesters are growing use, particularly among large farms with more than 1 hectare.

\section{Conclustion}

Migration has instead been found to be a part of a diversification strategy to "keep a foot on the farm", as the migrating peasant labour "hybrid features: peasant workers and urbanized villagers" (Lebailly Ph., J.Ph. Peemans, and $\mathrm{Vu}$ D.T. 2015). Migrating peasant labourer are able to be simultaneously peasants and labourer at the same time. Such an approach rules out the importance of "multiple job holding" (van der Ploeg and Jingzhong 2010), or "occupational multiplicity" (Breman 2007) or "diversified livelihoods"(Scoones 2009, Lahiri-Dutt, Alexander, and Insouvanh 2014). In other words, migration is therefore found to be simply a good choice in the peasants' livelihood portfolio, to diversify their incomes through low investment providing stable income. Evidence from Maithon village claimed that there is no remarkable agricultural labour deficit created due to internal migration in the meso level of a village. However, it also clear that rural households had difficulties in labour manafement, specially in peak time of rice season. The way that Maithon household adaptation with this new context including: 1) Keep rice production at the limited level while abandon other labour-cost farming activities. 2) Maximize the family labour arrangement. 3) Hire external labour and using mutual help, here we can emphasized the female migrant role. 4) Develop agricultural service rather than investment in technology change. It is interesting that in Maithon, when the migration decision was made, all family members also reached an agreement on how agricultural tasks and housework should be shared amongst all family members not only those who stay behind. The burden put on the ones who left behind are popular discourse which usually reported in migration researches (Bélanger and $\mathrm{Xu} \mathrm{Li} \mathrm{2009,} \mathrm{Bergstedt} \mathrm{2012,} \mathrm{Kazushi} \mathrm{and} \mathrm{Otzuka} \mathrm{2009).} \mathrm{The} \mathrm{household's} \mathrm{responses} \mathrm{collected}$ through the survey during this research indicated that they gave their consent for the migration of their family member due to monetary reasons; as their spouses can bring in stable cash income for the family. Even though the burden of work, primarily agriculture work, has increased, along with it incomes have also risen which has permitted them to manage by renting machine or labour during times of labour shortages. Moreover, the expansion of multifunction households and multi-spacial households. Maithon shows the same picture with other rural household in Red River Delta that majority of them cannot be referred to as "farming households" but instead as "rural households which continue to farm" as (Nguyen Thi Dien et al. 2015, Nguyen Thi Dien, Lebailly, and Vu 2014). These case studies challenge the traditional concept of household when defined them as "members living under the same roof". The strong commitments and obligations between family members show that this household model is well-functioning with mutual support divided across space.

\section{References}

Anh, D. N. (2003). Internal migration policies in the ESCAP region. Asia-Pacific population journal, 18(3), 27-40. https://doi.org/10.18356/f5ba72c7-en 
Anh, D. N. (2008). Labour migration from Viet Nam: Issues of policy and practice. International Labour Organization.

Bélanger, D., \& Li, X. (2009). Agricultural Land, Gender and Kinship in Rural China and Vietnam: A Comparison of Two Villages. Journal of Agrarian Change, 9(2), 204-230. https://doi.org/10.1111/j.1471-0366.2009.00201.x

Bergstedt, C. (2012). The Lie of the Land - Gender, Farm Work, and Land in a Rural Vietnamese Village. Social Anthropology School of Global Studies, University of Gothenburg, Gothenburg, Sweden.

Breman, J. (2007). The poverty regime in village India. New Delhi: Oxford University Press.

Bui, M., Be, Q. N., \& Dang, T. V. P. (2012). Agricultural land, peasant and rural development. Sociology, 3(119), 26-33.

GSO. (2011). Migration and Urbanization in Vietnam: Patterns, Trends and Differentials. Hanoi: GSO.

Hirsch, P. (2011). Afterward: re-agrarianisation or repositioning agrarian. In Wittayapak C., \& Vaddhanaphuti, C. (Eds.), Revisiting agrarian transformation in the greater mekong subregion: new challenges (pp. 185-188). Chiang Mai: RCSD.

Hoang, L. A., \& Brenda, S. A. Y. (2011). Breadwinning wives and "left-behind" husbands: Men and Masculinities in the Vietnamese Transnational Family. Gender and Society, 25(6), 717-739. https://doi.org/10.1177/0891243211430636

Hoang, X. T., Truong, T. A., Luu, T. Q., Dinh, T. G., \& Dinh, T. T. P. (2013). Food security in the context of Vietnam's rural-urban linkages and climate change (Edited by IIED). London, UK: International Institute for Environment and Development.

Kazushi, T., \& Keijiro, O. (2009). The increasing importance of nonfarm income and the changing use of labor and capital in rice farming: the case of Central Luzon, 1979-2003. Agricultural Economics, 40(2), 231-242. https://doi.org/10.1111/j.1574-0862.2009.00372.x

Lahiri-Dutt, K., Kim, A., \& Chansouk, I. (2014). Informal mining in livelihood diversification: mineral dependence and rural communities in Lao PDR. South East Asia Research, 22(1), 103-122. https://doi.org/10.5367/sear.2014.0194

Lebailly, Peemans, J., \& Vu, D. T. (Eds.). (2015). Rural development and small farmers in South East Asia: Lessons of experiences in Vietnam and Cambodia: Le GRAESE (Groupe de Recherches sur l'Asie de l'Est et du Sud-Est).

Minh, B., Bế, Q. N., \& Đặng, T. V. P. (2012). Ruộng đất, nông dân và mấy vấn đề phát triển nông thôn. Tạp chí Xã hội học, số, 3, 119.

Mus, P. (1952). Vietnam: a nation off balance. Yale Review, 41, 124.

Nguyen, T. D., Lebailly, \& Vu, D. T. (2014). Agricultural land conversion for industrialization: Livelihood along rural-urban continuum and mechanism of social differentiation in Hung Yen province, Vietnam. In Lebailly, Peemans, J., \& Vu, D. T. (Eds.), Rural development and small farmers in South East Asia: lessons of experiences in Vietnam and Cambodia. GRAESE: Groupe de Recherches Asie de l'Est et du Sud-Est.

Nguyen, T. D., Nguyen, T. M. K., Le, T. M. C., \& Lebailly. (2015). Duality of migrant lives: Gendered migration and agriculutral production in Red River Region, Vietnam. Paper read at 9es Journees de Recherches en Sciences Socials, 10-11 December 2015, at Nancy.

Nguyen, T. M. K., Nguyen, T. D., \& Lebailly. (2016). Agricultural Production in the context of Industrialization and Food Security in Vietnam. AGROFOR International Journal, 1(1), 86-94. https://doi.org/10.7251/AGRENG1601086N

Nguyen, T. P., Tran, N. T. M. T., Nguyen, T. N., \& Remco, O. (2008). Determinant and Impact of Migration in Vietnam. In Working Paper Series No. 2008/01, edited by The DEPOCEN working paper series. Amsterdam.

Peemans, J. P. (2013). A political economy of rural development in South East Asia in relation with the many versions of the disappearance of the peasantry. Louvain la Neuve: Centre d'Etudes du Développement, UCL.

Scoones, I. (2009). Livelihoods perspectives and rural development. The journal of peasant studies, 36(1), 171-196. https://doi.org/10.1080/03066150902820503 
van der, P., Jan, D., \& Ye, J. Z. (2010). Multiple job holding in rural villages and the Chinese road to development. The Journal of peasant studies, 37(3), 513-530. https://doi.org/10.1080/03066150.2010.494373

White, M. J., Yanyi, K. D., \& Dang, N. A. (2001). Implications of economic reform and spatial mobility for fertility in Vietnam. Population Research and Policy Review, 20(3), 207-228. https://doi.org/10.1023/A:1010604730408

\section{Copyrights}

Copyright for this article is retained by the author(s), with first publication rights granted to the journal.

This is an open-access article distributed under the terms and conditions of the Creative Commons Attribution license (http://creativecommons.org/licenses/by/4.0/). 